\title{
ASSESSING THE FIELD PLACEMENT IN INITIAL TEACHER EDUCATION: FINDING A BALANCE BETWEEN FORMATIVE AND SUMMATIVE ASSESSMENT
}

\author{
Deborah A. Chetcuti, Michael A. Buhagiar
University of Malta, Malta \\ Deborah A. Chetcuti, Michael A. Buhagiar
University of Malta, Malta \\ E-mail: deborah.chetcuti@um.edu.mt, michael.buhagiar@um.edu.mt
}

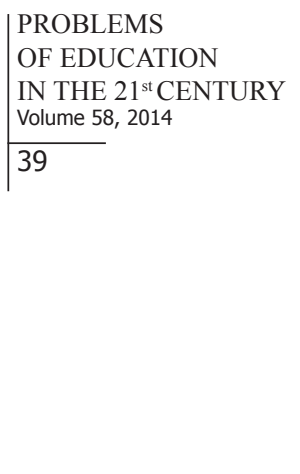

\begin{abstract}
The research study reported in this paper explores the issues and challenges faced by teacher educators when assessing student-teachers during their field placement. The key research question is: What are the issues and challenges faced by teacher educators and university administrators in relation to the formative and summative assessment of student-teachers during their field placement in Initial Teacher Education? The research tries to address this question by drawing on qualitative data from interviews with key academics and administrators at the University of Malta. The data from the interviews suggests that finding a balance within a university setting between the formative and summative aspects of assessment can create a potential conflict. This results in teacher educators focusing more on administrative demands for accountability and standards through summative assessment (also known as 'assessment of learning') rather than on the learning process through formative assessment (also known as 'assessment for learning'). The authors challenge this current view and, using examples from good practice, construct a model of assessment for the field placement that tries to improve the balance between formative and summative assessment.
\end{abstract}

Key words: formative assessment, summative assessment, field placement, initial teacher education.

\section{Introduction}

The field placement (also known as 'teaching practice' or 'teaching practicum' is considered to be a key factor in effective Initial Teacher Education (ITE) programs (Beck \& Kosnick, 2002; Darling-Hammond, 2006), as it provides an opportunity for teaching competence to be developed within an authentic learning community. The field placement, however, has a double role. First of all, it is 'an educative practicum' (Zeichner, 2002) where student-teachers can practise skills, develop competencies, try out new ideas and reflect on the construction of their teacher identity through interaction with teachers, fellow student-teachers and teacher educators. Secondly, it also serves as a summative evaluation of whether the student-teachers have achieved the required competencies that will allow them to be certified as teachers. This creates a number of challenges for teacher educators, as they have the dual role and responsibility of facilitating student-teacher learning and evaluating teaching competence (see Tang, 2003). While the first role is strictly professional, the second adheres to strict administrative guidelines and expectations. The main research question addressed in this paper therefore is: What are the issues and challenges faced by teacher educators and university administrators in relation to the formative and summative assessment of student-teachers during their field placement in ITE? 
Deborah A. Chetcuti, Michael A. Buhagiar. Assessing the Field Placement in Initial Teacher Education: Finding a Balance between Formative and Summative Assessment

\section{PROBLEMS \\ OF EDUCATION \\ IN THE $21^{\text {st }}$ CENTURY \\ Volume 58,2014 \\ 40}

\section{The Research Problem: Tensions between Formative and Summative Assessment}

The research problem emerged from the tensions experienced by the authors as teacher educators, particularly in their role as mentors and/or examiners of student-teachers during their field placement. The authors found the assessment of the field placement to be more problematic than traditional academic assessment (see Sharp, 2006). In reaction to this, drawing on a social cultural theoretical framework (see Rogoff, 1990; Wenger, 1998), the authors developed a view of assessment as a cultural activity where student-teachers negotiate their identities "through guided participation in a system of apprenticeship" (Rogoff, 1990, p. 155). The practicum assessment was envisaged in fact, as a process that was "being done with and for the student" (Klenowski, 2009, p. 89). This helped the authors to construe the assessment of the field placement as a formative experience which involves a two-way communication process between themselves and the student-teachers, and includes opportunities for learning from feedback and reflection (see Darling-Hammond \& Snyder, 2000). Similar to Zeichner (2010), the authors viewed the field placement experience as an opportunity for professional development and not only as a time for student-teachers to demonstrate or apply skills.

Working from the premise that becoming a teacher is a continual, active process rather than a product (see Darling-Hammond \& Snyder, 2000), the authors tried to create "communities of practice' (Lave \& Wenger, 1991) with the student-teachers during the field placement. Using formative assessment practices, they sought to help the student-teachers negotiate a sense of 'belonging' within the community of practice and 'becoming' more expert through active participation (see Lave \& Wenger, 1991). The authors' ultimate hope was that their view of assessment as a formative learning experience would enhance the continuous learning and development of student-teachers (see Smith, 2010). As a result of this professional growth, student-teachers would become capable of taking decisions and also make complex judgments about their own work and that of others (see Boud \& Falchikov, 2006).

The authors, however, also recognized that the assessment of the field placement has an additional summative function. This 'gate-keeping function' (see Smith, 2010) selects the competent teachers in order to protect the profession from incompetence. The certification of competent teachers is extremely important because, just as no one wants to be treated by an incompetent doctor, no one wants his or her children to be taught by teachers who have not reached the necessary satisfactory standards (see Bloxham, 2008).

The assessment of the field placement is particularly problematic when, as happens at the University of Malta the two apparently contradictory functions of assessment, that is the formative and summative dimensions, are carried out by the same person, the teacher educator. The embedded feedforward and judgmental roles create a stressful situation since the same person has to be both a supporter and judge at the same time (see Smith, 2006; Ciuffetelli-Parker \& Volante, 2009). These tensions were experienced by the authors during field placements as they tried to reconcile their assessment philosophy with the summative assessment that they were required to carry out. The authors felt that while they cherished their formative role, viewing themselves as mentors who were focused mainly on enabling student-teachers to decide where they were in their learning, where they needed to go and how best to get there (see Black \& Wiliam, 2009), their University was describing them as 'examiners' in its regulations (see University assessment regulations, 2009) and was concerned primarily that they pass a summative judgment of student-teachers.

\section{Assessment in Higher Education}

Research (Boud, 2007; Ferguson, 2011) suggests that assessment practices in Higher Education (HE) remain dominated by a focus on standards, the measurement of outcomes, certification and concomitant regulations. The role of assessment in relation to learning, although generally acknowledged, appears not to be well understood across HE (see Yorke, 2003). The 
failure of assessment practices in HE to reform along the lines noted at primary and secondary levels may be rooted in the greater demands for accountability (DeLuca \& Klinger, 2010) and

PROBLEMS

OF EDUCATION

IN THE $21^{\text {st }}$ CENTURY

Volume 58,2014

the increasing bureaucratization of universities which have become corporatized (Evans, 2011; Mayo, 2009). The resulting institutional pressures that relate to valuing 'efficiency', 'standards', 'league tables' and the 'marketplace' hinder the very the introduction of formative assessment in HE (Rorrison, 2010).

For the authors, as also reported in a study by Asghar (2012), the demands for quality assurance and high administrative demands were doing very little to empower them as academics to concentrate their efforts on creating a supportive learning environment for their student-teachers. On the contrary, they were concerned that their socio-cultural theoretical underpinnings were being 'silenced' (see Evans, 2011) in practice in view of the increased administrative demands of the university. As described by Evans (2011), they were feeling that assessment at university was a disempowering administrative procedure, with its own rules and regulations, which was not allowing them to take academic responsibility for the assessment of the field placement.

The reflection of these concerns led the authors to crystallize the focus of their research, starting by identifying the issues and challenges experienced by teacher educators and university administrators in the assessment of the field placement. University administrators were involved in the study since, apart from the tensions between formative and summative assessment, one of the factors that was having an impact on the assessment of the field placement was the increased bureaucratization of assessment practices within the context of HE. The authors hoped that by looking at the multiple perspectives of key players in the assessment process, they would be able to construct a model for the assessment of the field placement that tries to find a balance between all the tensions identified.

\section{Research Methodology}

\section{General Background of Research}

Currently, the Faculty of Education at the University of Malta provides two routes into teaching: a four-year Bachelor of Education (Honours) program (which is the focus of the present research) and a one-year Post Graduate Certificate in Education. For both ITE programs, the field placement is considered to be an essential element, as it allows the studentteachers to acquire key skills and competencies in teaching and learning, allows them to link theory and practice and become reflective practitioners (see Sultana, 1995; Bezzina \& Camilleri, 2001). As part of their degree, B. Ed. (Hons.) students are asked to spend a period of time in schools, which is referred to as 'field placement'. Their role and duties during these placements in schools vary according to their level of studies. In the first two years of the program, they simply carry out a number of observations and tasks and teach a number of lessons. In the third and fourth year of the program, they are in schools for a block period of six weeks. During these six weeks they are completely responsible for the classes that they have been assigned. Education students are referred to as 'student-teachers' during school placements.

Assessment of the field placement is carried out by two or three teacher educators (who are officially referred to as 'examiners') who visit the student-teachers on at least four separate occasions. The student-teachers are given oral and written feedback against a checklist of pre-set competencies. At the end of the field placement they are awarded a Pass or Fail. The teacher educators are expected to play a dual role during the practicum: They are expected to support the student-teachers by giving them "qualitative feedback which allows them to understand their strengths and areas which need improvement in order to grow and develop as professionals" (Assessment guidelines, 2006, p. 5), but at the same time they also need to act as examiners and award student-teachers a Pass or Fail. As examiners, the teacher educators need to abide by the University assessment regulations (2009) that govern all forms of assessments 
Deborah A. Chetcuti, Michael A. Buhagiar. Assessing the Field Placement in Initial Teacher Education: Finding a Balance between Formative and Summative Assessment

\section{PROBLEMS \\ OF EDUCATION \\ IN THE $21^{\text {st }}$ CENTURY \\ Volume 58,2014 \\ 42}

that contribute towards the award of any certification by the University. These regulations are based on a scientific model of achievement and reflect the harmonization process across European universities through accreditation systems that require an assessment to be measurable and transferable in order to ensure mobility and quality assurance across European universities (see Mayo, 2009).

\section{The Research Participants}

The participants of the study included five academics and five administrators from the University of Malta. The five academics, who worked within different area specializations at the Faculty of Education, had either carried out research in assessment or were in key administrative positions within the Faculty at the time of the study. The academics, therefore, for one reason or another were all well versed in assessment discourse. The five administrators, on the other hand, were chosen because of their assessment-related administrative responsibilities at that time either at Faculty or University levels. All ten participants gave their informed consent. Pseudonyms are used in this paper in order to preserve the anonymity of the participants.

\section{Data Collection and Analysis}

The data were collected through semi-structured interviews that allowed interaction with the participants of the study (see Fontana \& Frey, 2005). The idea was to obtain data that are rich in examples from practice and experience. It was thus decided to use broad open questions in order to encourage the participants to speak freely about their views on the assessment of the field placement. An interview schedule was prepared and this was used with the participants to ensure consistency (Cohen, Manion \& Morrison, 2007). The one-to-one interviews, which gave the participants a better chance to express personal views and opinions, were all carried out by one of the authors in order to establish an interviewing pattern. Each interview lasted approximately an hour and the questions asked were open ended. This allowed the participants of the study to express their views and opinions about various issues related to the field placement, such as the mentoring and examining role, the tensions and conflicts that arise from the formative and summative aspects of assessment, and the role of the field placement in the development of prospective teachers. The author knew the participants as colleagues, and this was used to the advantage of the research since the pre-existing relationship of trust and respect ensured that the data collected was as real and authentic as possible (see Cole \& Knowles, 2000).

From the outset the participants were aware of the views of the interviewer who approached the research trailing her value-laden knowledge (see Griffiths, 1998). However, this did not hinder the participants from expressing their own personal opinions in the knowledge that the authors were reflective and reflexive enough to present a multi-voiced perspective which was "a joint construction not transmission of knowledge and was characterized by negotiating feedback and respect for each other" (Cole \& Knowles, 2000, p. 197). The interviews were transcribed and sent to the participants to ensure that their views were being recorded correctly. The data were then analysed using a 'thematic analysis' (see Boyatzis, 1998) in order to develop a reflexive, multivoiced narrative (Denzin, 1994) of the participants' views. It is not the intention of the study to produce results that can be generalized. Instead, the intention is to provide views which "may have a shared meaning for others struggling with the same issues in their own pedagogic practice" (Asghar, 2012, p. 209).

\section{Results and Discussion}

As the authors coded the data to look for patterns, themes and underlying tensions (see Boyatzis, 1998), four major themes emerged from the issues raised by the participants of the study. These include: the challenge of assessing students within a bureaucratic university sys- 
Deborah A. Chetcuti, Michael A. Buhagiar. Assessing the Field Placement in Initial Teacher Education: Finding a Balance between Formative and Summative Assessment

tem; the dual role of teacher educators as mentors and examiners; the misuse of formative 43 feedback; and issues of fairness and equity in assessment practices.

\section{The Challenge of Assessing Students Within a Bureaucratic University System}

Within HE the assessment discourse has become mainly concerned with quality assurance, achievement, standards, procedures and measurement of outcomes (see Boud, 2007). According to Evans (2011), this administrative takeover of assessment procedures in universities results in the silencing of academic discourse in favour of prescriptive rules and regulations. In line with the arguments put forward by Boud (2007) and Evans (2011), Simon, one of the academics, felt like that his thinking about assessment had changed in response to the increased bureaucratisation of assessment practices within the University of Malta. He claimed that the introduction of the University assessment regulations (2009), which follow a scientific model and focus mainly on procedures on how to ensure fair practice in examinations and marking, curtailed his discretionary judgment as an academic and teacher educator. Recognising these regulations as the 'law', Simon disclosed that although he still endorses 'assessment for learning' principles (see Assessment Reform Group, 2002), he is not being given the space to put these principles into practice. This is how he put it:

I believe that formative assessment should be part of assessment at University, but it's not a question of what I believe any more... it's a question of what is allowed. Formative assessment is not allowed at University. Feedback doesn't even feature in the regulations at the University.

Margaret, one of the administrators, concurred with Simon. She said:

I think the system is not very conducive to lecturers giving feedback to studentteachers... from an administrative perspective, if any of the students ask me what they need to do if they do not like a mark, we always tell them that this can be done through a revision of the paper. We never tell them to go to the lecturer...

Asghar (2012) reported similar disenchantment with educational principles among academics in a British university:

... The tensions created by the demands of quality assurance, institutional policy drives and economic constraints on time do little to encourage academics to feel empowered to concentrate their assessment efforts towards a more supportive learning environment. (p. 206)

In the present study, however, Simon was the only academic who opined that the assessment regulations of the University are constraining his formative assessment practices. Peter, another academic, for example, argued that although he knows that these regulations only require him to give a summative judgment of student-teachers' performance, in reality he still uses the assessment process to support student-teachers and give them formative feedback. Peter was adamant about this:

... I know that there are the assessment regulations, but this does not tell me how I should deal with my students. Even though the regulations do not allow for formative feedback, I still tell student-teachers what I think of their performance and try to be as clear and realistic as possible... 
Deborah A. Chetcuti, Michael A. Buhagiar. Assessing the Field Placement in Initial Teacher Education: Finding a Balance between Formative and Summative Assessment

PROBLEMS

OF EDUCATION

IN THE $21^{\text {st }}$ CENTURY

Volume 58,2014

44

\section{The Dual Role of Teacher Educators as Mentors and Examiners}

The administrators in the study emerged as being aware that the assessment process at University, apart from the summative dimension with which they are directly involved in their work, carries an additional formative potential for their academic colleagues. This is how Diane, an administrator, described these two facets of assessment:

From a bureaucratic point of view and of regulations, assessment is the means by which students gain their ECTS credits. So I think that this is the first purpose of assessment. Assessment is also the means by which you give students an indication of how they are performing in a particular unit and the course. I understand that assessment has two roles, the role to help the student improve and to tell the student what standards they have achieved.

But while this duality poses no problem for administrators, it raises an important 'professional dilemma' for academics. For Simon, the solution was to practically forfeit the formative dimension of his assessment practices. The remaining four academics claimed to experience tension as a result of having to work with a regulatory structure that does not also reflect their 'for learning' assessment beliefs. They identified in fact their dual role as 'gatekeepers' and protectors of the profession and 'mentors' who provide support and guidance to student-teachers (see Rorrison, 2010) as one of the major challenges they face during the field placement. Marika, an academic, aptly expressed the difficulties encountered:

It's a double-sided coin. You're always mentoring them in a sense... yet at the same time you're assessing them. It's a difficult balance and I think there's no clear cut off point when you say at this point I'm mentoring... and at this point I'm examining... As much as I try to be a mentor, the students know that at the end of the day I'm there to pass or fail them. Obviously, the way I give them feedback is important, but at the end of the day however much feedback I give them, the element of examination remains and in the end they always ask but is it a Pass or a Fail.

The prospect of having to provide guidance and support and at the same time give a summative judgment of performance arguably creates what Ciuffetelli-Parker and Volante (2009) describe as 'irreconcilable tensions'. Notwithstanding this, these four academics claimed to be forging ahead in their pursuit to try to reconcile the formative and summative aspects of the assessment process. Peter and Joanne, two of these four academics, reported that they are able to manage their dual role as mentor and judge without particular difficulties. Like Stobart (2008), Peter sees the possibility of integrating the formative and summative aspects of assessment as part of a loop:

I see the summative aspect of assessment as part of the whole process of formative assessment. I don 't just give a grade and that's it... All that I do in the assessment process, including when I give a summative grade, is giving students feedback on how they are progressing... I do not see the two things as separate...

Joanne, on the other hand, is more interested in finding a balance between these two purposes of assessment:

There is a bit of discomfort because as mentor I need to help and support students, but then I also need to see whether that help and support has been translated into better performance. It is a little bit awkward, but in my mind, I feel that the two are clear. I feel that I can do both. 
The other three academics in the study, including Simon, continued to express their reservations about the manageability of this dual role. A response to this duality depends in reality on whether teacher educators are interested in observable outcomes (that is, what they are actually seeing the student-teacher do) or the potential of the student-teacher who is in the middle of a learning experience (see Smith, 2006). Depending on their interest, teacher educators would then carry out their assessing role either by focusing on competence or learning (see Tang \& Harrison, 2011). The real question remains, however, whether these two roles can be carried out concurrently by the same person. The authors are of the idea that should mentors also have a judgmental role, student-teachers might then be reluctant to admit mistakes and ask for helpan eventuality that would diminish their learning experience (see Yorke, 2003). To have a truly 'humane and supportive mentoring' system (see Rorrison, 2010), the professional interactions between mentor and mentee cannot be shackled by the possibility of failure.

\section{The Misuse of Formative Feedback}

Another important issue that emerged from the data was the concern, raised by both teacher educators and university administrators, that the feedback which is being given to student-teachers when teacher educators visit them during the field placement is not being used by student-teachers to improve their learning. As argued in the previous two sections, administrative concerns and the challenge of being both 'mentor' and 'examiner' at the same time somewhat constrain the formative aspect of assessing the field placement. Still, all the teacher educators, except for Simon, stated that in some way or another they offer 'for learning' feedback to student-teachers during the field placement. For instance, Peter confided:

It is my responsibility to show student-teachers where their strengths are and how they can improve their weaknesses...

What the teacher educators and administrators suggested, however, was that the studentteachers are not using formatively this feedback. This comment by Vincent, an administrator, expressed this general feeling:

Student-teachers are not using the comments in a formative manner... they interpret the comments in whatever way they want. Lecturers are using comments to try and help the students to grow, but the students, especially the ones who are failing, use lawyers to interpret the comments so that they can get a decision of failure revoked. For example, the student-teachers very often tell me, 'But why did my university lecturer give me positive comments and then fail me in the end?' The formative aspect of assessment is being lost on student-teachers. All the student-teachers want is to pass their field placement and they feel that any comments of encouragement that have been given to them by lecturers (in a formative manner) give them the right to pass.

When, as in such cases, feedback is not used to improve practice and promote learning, feedback loses its value (see Wiliam, 2000; Sadler, 2009). The participants in this study seemed to concur that student-teachers are squarely to blame for this loss, as they quite deliberately misuse feedback. But there are other plausible reasons for this. It could be a lack of communication between teacher educators and student-teachers, or else student-teachers might still lack the necessary understanding of or the ability to use the feedback that comes their way (see Price, Handley, Millar \& O’Donovan, 2010). Within a results-oriented HE culture, student-teachers are possibly only interested in whether they have passed or failed their field experience. Consequently, they may wish to interpret the feedback given to them only in terms of whether it supports the final judgment which they are given. In this scenario, any positive comments that are given by teacher educators to encourage and help student-teachers to improve their practice may be simplistically construed by the recipients as tangible evidence that they are doing well. 
Deborah A. Chetcuti, Michael A. Buhagiar. Assessing the Field Placement in Initial Teacher Education: Finding a Balance between Formative and Summative Assessment

OF EDU

PROBLEMS

IN THE $21^{\text {st }}$ CENTURY

Volume 58,2014

For the authors, one of the main problems is that formative feedback is being given to studentteachers in a summative context. This results in mixed messages and confusion for the studentteachers. Diane, an administrator, crystallised this crucial point by saying:

Student-teachers have told me that the oral and written feedback that they get does not match. They do not understand how their university lecturers tell them that they are improving, that they are doing well, and yet sometimes they still fail their field placement. They question the positive feedback they receive when in the end they still fail. I understand that there is the dilemma that you don't want to discourage students when they have the potential for improvement. At the same time you don't want to give the impression that someone is doing well when in reality this is not the case, when you are expecting a huge leap in the performance of students. Now how you get that message across is in my view the crux of the matter...

The data seems to suggest that although feedback is an essential characteristic of any formative learning experience, during the field placement student-teachers are only using the feedback comments to try to guess whether they have actually passed or failed their practicum. The checklist of competencies used by teacher educators to give their feedback and comments is creating what Cochran-Smith (2003) describes as an 'outcomes loop' in which all learning is considered to be observable and measurable. In this study, the teacher educators and administrators perceived student-teachers to be misusing the received feedback by trying to turn it into a measure of a summative performance. There thus appears to be a lack of a shared understanding between teacher educators and their students of what is being assessed (see Smith, 2006).

\section{Issues of Fairness and Equity in Assessment Practices}

Issues of fairness and equity were mentioned by nine out of the ten participants of the study. These academics and administrators agreed that the assessment of the field placement should be a fair and equitable experience. Their claims to the contrary were based on the fact that while all the other components of the B.Ed. (Hons.) program are credited by a grade and a corresponding percentage mark that contributes directly to the final classification of the degree, the field placement is assessed on a 'Pass/Fail' basis that carries no real weight in the final classification. Conscious of the fact that the classification provides a license into practice (see Knight, 2007), these participants find it problematic that the assessment of the practicum performance makes no difference to the final classification except for when the Faculty's Degree Classification Board takes it into consideration to assign a First Class Honours degree (see University of Malta, 2006). Here are some of their comments:

If you are giving a 'Pass/Fail' there is no number which you can add at the end towards the classification... you get a zero whether you have passed or failed. If one is doing brilliant and one is doing badly, they are both going to get a zero towards their classification. (Margaret, an administrator)

Once our students are being prepared for a professional degree, it is not fair that the practicum is not being recognised in the transcript like all the other study units. (Pauline, an academic)

The thrust of their argument was that the degree classification should be strongly related to the student-teachers' teaching skills (see Cope, Bruce, McNally \& Wilson, 2003; Sharp, 2006) and that this is only possible if the field placement is graded. For them, the introduction of fine-tuned grading would provide "a concise method of conveying levels of academic achievement and expressing them in a common currency" (Sadler, 2009, p. 810). This departure from the current 'Pass/Fail' system is desired by these nine participants as it would redress what they perceive as an unfair situation that does not differentiate between student-teachers who produce exemplary work and others who just get by. This is what Joanne, an academic, said: 
We have students who barely make it and students who excel... at the moment we're not differentiating between these types as the assessment we're giving is too broad. It doesn't do justice to those who push the boat out further, nor does it reveal that some students just make the grade.

Warren, one of the administrators, went a step further by suggesting that the 'Pass/Fail' system even might favour some students when it comes to finding employment to the detriment of the more deserving ones:

Unfortunately, in an interview, it might be that the person who just scraped through can sell himself better and it'll be he who'll get the job. In essence, the 'pass' does not show the quality of the work done.

The arguments made by both academics and administrators hinge on the understanding that assessment practices form a 'positional good' which provides entry into desired occupations, status, wealth and power (see Griffiths, 2009). For the authors, however, such arguments reaffirm the predominant view of assessment as a summative process with the purpose of selecting students and differentiating among individuals to select those who are considered to be the best against measurable criteria (see Sambell, McDowell \& Montgomery, 2013). Unlike the participants of the study, the authors do not believe that grading the field placement, however fine-tuned, would make the experience more equitable. Instead, they would argue like Boud (2007) that a mark or grade could destroy meaning, as such measures only acquire meaning if employed in highly comparable, if not identical, contexts. But with field placements this search for uniformity is problematic. The fact that practicum placements are in different schools places significantly different demands on student-teachers, provides them with different levels of support and affects their performance in complex and unpredictable ways (Cope et al., 2003). One cannot therefore expect grading - which pertains to the scientific measurement model that treats knowledge as unidimensional, context-free and task specific - to capture the complexities and situatedness of teaching (see Martin \& Cloke, 2000; Sambell et al., 2013).

\section{Implications for Practice}

This study aimed to explore the issues and challenges that teacher educators and university administrators face in connection with the assessment of student-teachers during their field placement. Although there is general agreement in the literature that the field placement is a key aspect of ITE programs (see Beck \& Kosnik, 2002), it is also clear that the assessment of the field placement is more problematic than the more traditional academic assessment (see Sharp, 2006). This study has shown that the main challenges linked to the assessment of the field placement arise from a dual assessment role. All the participants of the study agreed that in principle the assessment of the field placement should be a formative experience, an occasion for teacher learning to take place (see Zeichner, 2010). However, in practice, as reported by both the teacher educators and the administrators who participated in the study, the assessment of the field placement within the context of a degree program has largely become a summative tool which certifies student-teachers as competent professionals and is controlled by University rules and regulations. This reflects a reality characterised by complex decisions being taken within a bureaucratic model of assessment that is dominated by testing competence in a manner which is rule governed and highly prescribed (see Darling-Hammond, 2006). Put differently, administrative concerns - which are grounded within what Boud (2007) describes as a dominant discourse of assessment based on measurement and certification - are helping to sideline the formative dimension from the assessment of the practicum. 
Deborah A. Chetcuti, Michael A. Buhagiar. Assessing the Field Placement in Initial Teacher Education: Finding a Balance between Formative and Summative Assessment

BLEMS

OF EDUCATION

IN THE $21^{\text {st }}$ CENTURY

Volume 58,2014

For the participants of the study, the way forward in the assessment of the field placement is to introduce fine-tuned grading which they believe would eliminate sending mixed messages to student-teachers and be fairer to student-teachers by acknowledging their efforts in a measurable way. The academics and administrators in the study made this proposal in spite of opining that student-teachers can only grow and learn from formative feedback. Giving issues of equity and fairness as their main rationale, these participants argued that fine-tuned grading will solve the problems of misinterpretation of feedback and create a language of communication that is better understood by the student-teachers. For the authors, however, this is an overly simplistic solution that does not take into account the complexity of teaching. Moreover, this increased bureaucratization of assessment positions student-teachers as passive subjects (see Boud, 2007), which is at odds with the view of assessment practices as a potential for learning (see Kvale, 2007).

For the authors, the challenge therefore is "to find ways of thinking about assessment that have a positive consequential influence on learning and then develop the assessment practices that could accompany such a conception" (Boud, 2007, p. 19). The field placement has the potential to become an authentic learning experience if, following Wenger (1998), teacher educators and administrators look at the practicum not simply as an experience for developing individual competences, but rather as an experience located within a community of practice. The partnerships that are formed within these communities among teacher educators, administrators, student-teachers and school teachers create a better support system that will allow student-teachers to develop their teacher identity along their journey of becoming (see Boud \& Falchikov, 2006). However, this calls for changes in the way in which the assessment of the field placement is carried out in the Faculty of Education, University of Malta. These changes have to be clearly considered and based on sound theoretical frameworks as "assessment affects people's lives... the future directions and careers of students depend on it" (Boud \& Falchikov, 2007, p. 3).

\section{A Proposal for a Good Field Placement Experience}

Based on what has been learned from this study and in the belief that it is possible to attain a balance between the formative and summative purposes of assessment during the field placement, the authors would like to propose that a good field placement experience requires the following three key elements.

\section{Creating a Safe Learning Community}

Creating a learning community where learning and assessment can be framed as a cooperative and shared social experience (Lave \& Wenger, 1991) is the first pre-requisite of a good field placement experience. This can lead to the apprenticeship model where the expert shows the apprentice how to do a task, the apprentice observes before starting to practice the skills involved, and then gradually takes more responsibility of his or her own learning. Within this model, the student-teachers learn within a community which includes co-operating school teachers who act as mentors, teacher educators who offer professional advice and peers who provide mutual support and encouragement. The success of these communities calls for better partnerships among academics, administrators and field professionals (Boud \& Falchikov, 2006). The assignation of a school mentor who works closely with both teacher educators and the student-teacher within the "community of practice' is important because in "a socio-constructivist view, community is not just a frill; it is fundamental to effective learning" (Beck \& Kosnick, 2006, p. 74). It is within this community that the student-teachers can feel safe enough to be creative and to show vulnerability as they develop a positive and supportive relationship with their mentors (see Dillon, 2010). Given the reciprocal dynamics of such a community, student-teachers become active participants in the assessment process rather than passive recipients of information about their competences. 


\section{Making the Field Placement an Authentic, Formative Learning Experience}

The field placement experience should be considered as a professional practicum or a 'reflective practicum'. Drawing on the apprenticeship model (see Kvale, 2007), the studentteachers start their journey of becoming teachers in a learning community where they learn from their mentor teacher as well as from the university teacher educators who visit them as advisors and 'critical friends'. While there is no formal assessment in terms of credit or grades, the student-teachers would be getting continuous feedback from their university lecturers and school 'mentors' that identifies the gaps in their learning and reinforces their teacher identity. In these learning communities, a shared meaning of assessment is developed and "the focus of assessment becomes mapping future learning growth and social support rather than measuring past performance" (Lave \& Wenger, 1991, p. 55). In this way, the formative purpose of assessment is completely separated from its summative function, and certification is no longer based on observed competences. The 'new' role of the teacher educator would be that of 'expert' or 'master' who guides the novice teacher into full participation in the socio-cultural practices of the teaching community (see Wenger, 1998). When the responsibility of the teacher educator is no longer linked to passing judgements, the focus of his or her interactions with studentteachers can shift to progress as they reflect and transform their sense of 'self' through learning conversations and experiences within the learning community (Rorrison, 2010).

The field placement experience can also be supported by weekly reflective seminars during which the student-teachers can interact with their university lecturers and reflect on critical incidents taking place in their classrooms (see Dillon, 2010). This provides student-teachers with the opportunity to step back, reflect and form a relationship of trust with their university lecturers outside the school context. By so doing, student-teachers become "partners in our assessment communities, rather than passive recipients of the judgments we mete out" (Sambell et al., 2013, p. 133).

\section{Certifying Teachers Summatively on the Basis of Multiple Sources of Information}

As argued previously, if the field placement is to become a professional learning experience, it cannot be constrained by fears of a summative evaluation or judgment. Nevertheless, the field placement is part of a university degree that provides students with a three tiered final degree classification (first, second or third class) and student-teachers need to be certified as professional teachers. This renders it necessary to put in place some form of summative judgment of the field placement that contributes directly to the final degree classification and also provides qualitative evidence that the required teaching standards have been reached. The validity of these judgements thrives when multiple sources of information are taken into consideration, as "an isolated sample of performance of a single genre of data is insufficient to inform judgments about learning, teaching, program development or candidate competence" (Darling-Hammond \& Snyder, 2000, p. 528).

The authors would therefore like to suggest that the summative assessment of the field placement is carried out on the basis of a number of factors and derived from multiple sources. These factors can include written evaluations and critical reflections by the student-teachers that are assessed by university lecturers (see Wiliam, 2000); attestations from school mentors and university lecturers acting as advisors and critical friends and a final evaluation by university lecturers acting as examiners who visit schools in the final weeks of the field placement. These can be presented in a teaching portfolio that builds an ongoing narrative of the student-teachers as they journey through the field placement. The student-teachers can then be interviewed in order to explain and provide a rationale for their practice. Following the interview, the 'examining board' can award the student-teacher a 'distinction', 'merit', 'pass' or 'fail' on the basis of all the collated evidence. These descriptors of practice can then be converted into a measurable mark or grade for the purpose of degree classification. This comprehensive procedure would 
Deborah A. Chetcuti, Michael A. Buhagiar. Assessing the Field Placement in Initial Teacher Education: Finding a Balance between Formative and Summative Assessment

OF EDUCAT

N THE $21^{\text {st }}$ CENTURY

Volume 58,2014

ensure that the summative, multi-sourced description of the student-teacher's competences gives an in-depth view of his or her development from 'novice'/'apprentice' to 'more expert'.

\section{Conclusion}

The main suggestion being made in this paper is to re-conceptualise the purpose of the field placement. This would basically entail shifting the purpose of the practicum from the certification of student-teachers to providing them with an authentic, learning professional experience. Learning within an apprenticeship model would thus become the main focus of the field placement experience. This can be achieved by creating effective 'learning communities' around the field placement that should move the practicum experience "beyond the realm of purely cognitive to acknowledge that learning is also a profoundly reflexive, social and emotional phenomenon" (Sambell et al., 2013, p. 9). Through these communities, the focus of the assessment experience becomes the immediate and future learning; the final summative evaluation, based on multiple sources of evidence, can then be seen as a snapshot of the whole assessment process. But if these communities are to take shape and bear fruit, it is essential that all the key players in ITE institutions and collaborating schools recognise and act upon the great learning potential of assessment during field placement. What is being proposed certainly represents a shift from the 'normal' assessment of the practicum and consequently may give rise to fear and scepticism. Still, the rewards of introducing and nurturing these 'learning communities' promise to be great, as they may serve to transform the well-documented formative and summative assessment tensions that characterise the field placement into learning opportunities.

\section{Acknowledgements}

Thanks to the academic and administrative colleagues at the University of Malta who generously offered to share their views and insights.

\section{References}

Asghar, M. (2012). The lived experience of formative assessment practice in a British university. Journal of Further and Higher Education, 36 (2), 205-223.

Assessment guidelines (2006). Assessment Committee, Faculty of Education, University of Malta, Malta.

Assessment Reform Group (2002) Assessment for learning: 10 principles (poster). Available online: $\mathrm{http} / / /$ www.aaia.org.uk/afl/assessment-reform-group/ (accessed 26 October 2013).

Beck, C., \& Kosnik, C. (2002). Components of a good practicum placement: Student teacher perceptions. Teacher Education Quarterly, 29 (2), 81-98.

Bezzina, C., \& Camilleri, A. (2001). The professional development of teachers in Malta. European Journal of Teacher Education, 24 (2), 157-170.

Black, P., \& Wiliam, D. (2009). Developing the theory of formative assessment. Educational Assessment, Evaluation and Accountability, 21 (1), 5-31.

Bloxham, S. (2008). Assessment in teacher education: Stakeholder conflict and its resolution. Practitioner Research in Higher Education, 2 (1), 13-21.

Boud, D. (2007). Reframing assessment as if learning were important. In D. Boud \& N. Falchikov (Eds.), Rethinking assessment in higher education. Routledge, London, UK, pp. 14-26.

Boud, D., \& Falchikov, N. (2006). Aligning assessment with long term learning. Assessment \& Evaluation in Higher Education, 31 (4), 399-413.

Boud, D., \& Falchikov, N. (2007). Introduction: Assessment for the longer term. In D. Boud \& N. Falchikov (Eds.), Rethinking assessment in higher education. Routledge, London, UK, pp. 3-13.

Boyatzis, R. E. (1998). Transforming qualitative information: Thematic analysis and code development. SAGE, Thousand Oaks, CA, USA.

Ciuffetelli-Parker, D., \& Volante, L. (2009). Responding to the challenges posed by summative teacher candidate evaluation: A collaborative self-study of practicum supervision by faculty. Studying Teacher Education, 5 (1), 33-44. 
Cochran-Smith, M. (2003). Assessing assessment in teacher education. Journal of Teacher Education, 54 (3), 187-191.

Cohen, L., Manion, L., \& Morrison, K. (2007). Research methods in education. Routledge, London, $\mathrm{UK}$.

Cole, A. L., \& Knowles, J.G. (2000). Researching teaching: Exploring teacher development through reflexive inquiry. Allyn \& Bacon, Boston, USA.

Cope, P., Bruce, A., McNally, J., \& Wilson, G. (2003). Grading the practice of teaching: An unholy union of incompatibles. Assessment \& Evaluation in Higher Education, 28 (6), 673-684.

Darling-Hammond, L. (2006). Powerful teacher education. Jossey-Bass, San Francisco, CA, USA.

Darling-Hammond, L., \& Snyder, J. (2000). Authentic assessment of teaching in context. Teaching and Teacher Education, 16, 523-545.

DeLuca, C., \& Klinger, D. A. (2010). Assessment literacy development: Identifying gaps in teacher candidates' learning. Assessment in Education: Principles, Policy \& Practice, 17 (4), 419-438.

Denzin, N. K. (1994). The art and politics of interpretation. In N.K. Denzin \& Y.S. Lincoln (Eds.), Handbook of qualitative research. SAGE, Thousand Oaks, CA, USA, pp. 500-515.

Dillon, D. (2010). Building from teaching experience: Factors that make teacher education effective. Keynote address at the annual conference of the Canadian Society for the Study of Education (CSSE), 28 May - 1 June, Montreal, Canada.

Evans, A. (2011). Governing student assessment: Administrative rules, silenced academics and performing students. Assessment \& Evaluation in Higher Education, 36 (2), 213-223.

Ferguson, P. (2011). Student perceptions of quality feedback in teacher education. Assessment \& Evaluation in Higher Education, 36 (1), 51-62.

Fontana, A., \& Frey, J. H. (2005). The interview: From neutral stance to political involvement. In N. K. Denzin \& Y.S. Lincoln (Eds.), The SAGE handbook of qualitative research. SAGE, Thousand Oaks, CA, USA, pp. 695-728.

Griffiths, M. (1998). Educational research for social justice. Open University Press, Buckingham, UK.

Griffiths, M. (2009). Justice, joy and educational delights. Available online: http://www.morwennagriffiths.pwp.blueyonder.co.uk/social_justice.htm (accessed 6 October 2011).

Klenowski, V. (2009). Assessment for learning revisited: An Asia-Pacific perspective. Assessment in Education: Principles, Policy \& Practice, 16 (3), pp. 277-282.

Knight, P. (2007). Grading, classifying and future learning. In D. Boud \& N. Falchikov (Eds.), Rethinking assessment in higher education. Routledge, London, UK, pp. 72-86.

Kvale, S. (2007). Contradictions of assessment for learning in institutions of higher learning. In D. Boud \& N. Falchikov (Eds.), Rethinking assessment in higher education. Routledge, London, UK, pp. 57-71.

Lave, J., \& Wenger, E. (1991). Situated learning: Legitimate peripheral participation. Cambridge University Press, Cambridge, UK.

Martin, S., \& Cloke, C. (2000). Standards for the award of qualified teacher status: Reflections on assessment implications. Assessment \& Evaluation in Higher Education, 25 (2), 183-190.

Mayo, P. (2009). Competitiveness, diversification and the international higher education cash flow: The EU's higher education discourse amidst the challenges of globalisation. International Studies in Sociology of Education, 19 (2), 87-103.

Price, M., Handley, K., Millar, J., \& O'Donovan, B. (2010). Feedback: All that effort, but what is the effect? Assessment \& Evaluation in Higher Education, 35 (3), 272-289.

Rogoff, B. (1990). Apprenticeship in thinking: Cognitive development in social context. Oxford University Press, New York, USA.

Rorrison, D. (2010). Assessment of the practicum in teacher education: Advocating for the student teacher and questioning the gatekeepers. Educational Studies, 36 (5), 505-519.

Sadler, D. R. (2009). Grade integrity and the representation of academic achievement. Studies in Higher Education, 34 (7), 807-826.

Sambell, K., McDowell, L., \& Montgomery, C. (2013). Assessment for learning in higher education. Routledge, London, UK.

Sharp, S. (2006). The grading of placement in initial teacher education in Scotland. Scottish Educational Review, 38 (2), 145-157.

Smith, K. (2006). The function of modelling. Educational Research \& Evaluation, 13 (3), 279-293.

Smith, K. (2010). Assessing the practicum in teacher education: Do we want candidates and mentors to agree? Studies in Educational Evaluation, 36, 36-41. 
Deborah A. Chetcuti, Michael A. Buhagiar. Assessing the Field Placement in Initial Teacher Education: Finding a Balance between Formative and Summative Assessment

PROBLEMS

OF EDUCATION

IN THE $21^{\text {st }}$ CENTURY

Volume 58,2014

Stobart, G. (2008). Testing times: The uses and abuses of assessment. Routledge, London, UK.

Sultana, R. G. (1995). Developing a vision for teacher education programmes: A values-based approach. European Journal of Teacher Education, 18 (2), 215-229.

Tang, S. (2003). Challenge and support: The dynamics of student teachers' professional learning in the field experience. Teaching and Teacher Education, 19, 483-498.

Tang, J., \& Harrison, C. (2011). Investigating university tutor perceptions of assessment feedback: Three types of tutor beliefs. Assessment \& Evaluation in Higher Education, 36 (5), 583-604.

University assessment regulations (2009). Available online: http://www.um.edu.mt/registrar/regulations/ general/assessment_regulations (accessed 20 October 2012).

University of Malta (2006). Bye-Laws of 2006 in terms of the general regulations for university undergraduate awards, 2004 for the degree of Bachelor of Education (Honours). Available online: http://www.um.edu.mt/registrar/regulations/faculties/educ/bedh-bl-2006 (accessed 25 October 2013).

Wenger, E. (1998). Communities of practice: Learning, meaning and identity. Cambridge University Press, Cambridge, UK.

Wiliam, D. (2000). Integrating formative and summative assessment. Keynote address at the annual conference of the Association for Educational Assessment (Europe) (AEA-Europe), 9-11 November, Prague, Czech Republic.

Yorke, M. (2003). Formative assessment in higher education: Moves towards theory and the enhancement of pedagogic practice. Higher Education, 45, 477-501.

Zeichner, K. (2002). Beyond the traditional structures of student teaching. Teacher Education Quarterly, 29 (2), 59-64.

Zeichner, K. (2010). New epistemologies in teacher education. Rethinking the connections between campus courses and field experiences in college and university-based teacher education. Revista Inteuniversitaria de Formacion del Profesorado, 68, 123-149.

Advised by Vincentas Lamanauskas, University of Siauliai, Lithuania

Received: September 08, 2013

Accepted: January 06, 2014

Deborah A. Chetcuti

PhD., Associate Professor, Department of Maths, Science \& Technical

Education, University of Malta, 4 Palm Court

Triq Dun Karm Lia , Lija LJA 1411, Malta.

E-mail: deborah.chetcuti@um.edu.mt

Michael A. Buhagiar

PhD., Senior Lecturer, Department of Maths, Science \& Technical Edu-

cation, University of Malta, Malta.

E-mail: michael.buhagiar@um.edu.mt 